\title{
Upgrading Indonesian Local Ethnomedicinal Knowledge with Molecular Phylogenetics
}

\author{
Brazia $\mathrm{AC}^{1}$, Adi $\mathrm{LT}^{2}$, Kaho $\mathrm{MR}^{3}$, Lindawati ${ }^{4}$, Rosaria ${ }^{1,5,}$, Rustiami $\mathrm{H}^{6}$, Sukara $\mathrm{E}^{1,7,8}$ \\ ${ }^{1}$ Department of Biology, Surya University, Great Western Resort, Tangerang, Banten 15143 \\ ${ }^{2}$ Department of Environmental Engineering, Surya University, Great Western Resort, Tangerang, Banten 15143 \\ ${ }^{3}$ Faculty of Agriculture, Nusa Cendana University, Kupang 85001, Indonesia \\ ${ }^{4}$ Department of Chemical Engineering, Surya University, Great Western Resort, Tangerang, Banten 15143 \\ ${ }^{5}$ Department of Zoology, University of Oxford, Oxford OX1 3SZ \\ ${ }^{6}$ Botany Division, Research Center for Biology, Indonesia Institute of Sciences, Cibinong 16911, Indonesia \\ ${ }^{7}$ Study Center for Environmental Ethics, Universitas Nasional, DKI Jakarta 12520, Indonesia \\ ${ }^{8}$ Indonesian Academy of Sciences, Perpustakaan Nasional RI, DKI Jakarta 10110, Indonesia \\ *Corresponding author. Email: rosaria@surya.ac.id
}

\begin{abstract}
With at least 200 ethnic groups and 30.000 medicinal plants used in Jamu formulations, Indonesia is one of the largest natural drug dispensaries in the world. Ethnomedicine-directed bioprospecting has been used to accelerate drug discovery. Little is known about the coverage of ethnomedicinal studies in Indonesia. The quest to obtain drugs from plants also remains elusive. Nature-derived approved drugs worldwide have come mostly from drug-productive families that tend to be clustered in the phylogenetic tree, thus these families should be the basis of bioprospecting focus. We presented a review of ethnomedicinal research conducted across Indonesia and recommend strategic approaches to accelerate the translation of traditional knowledge into the clinic. We identified several plant species commonly used with similar or different purposes within different places, empirical pharmacological studies, regions that are understudied, and comparison with plants whose metabolites have been used for the development of approved medicine worldwide. Combination of ethnomedicinal knowledge with molecular phylogenetics, -omics, Bioactivity-guided bioprospecting, DNA barcoding, and Global Biodiversity Information Facility (GBIF) software will enable more efficient and environmentally friendly drug discovery process as well as commercial production. Altogether, this proposed method will be a game-changer in the exploration of the largely untapped chemical diversity of Indonesian flora.
\end{abstract}

Keywords: Indonesia, ethnomedicine, molecular phylogenetics, Global Biodiversity Information Facility, DNA barcoding

\section{INTRODUCTION}

Indonesia is the biggest archipelagic country in the world. Coupled with the tropical climate, Indonesia hosts various types of ecological niche for animals and plants, making Indonesia one of the biggest biodiversity vessels in the world [1-3]. The plants particularly have been used by the Indonesians for numerous purposes, one of them being a natural resource for natural drugs. Unlike Traditional Chinese Medicine (TCM) or Ayurveda from India, the ethnic groups in Indonesia have very few records about their knowledge on medicinal plants, instead, they passed them down to their descendants from time to time viva voce, as Jатu formulations [4]. These Jamu formulations have been used by the ethnic people as the cure for several types of disease [5,6] and inspirations for many synthetically synthesized drugs available around us now. Coinciding with our continuous needs for new effective drugs, Indonesia's plant biodiversity can still be leveraged for its potential as natural drug resources.

Diverse ethnomedicinal research throughout Indonesia have been done from time to time, from the western part of
Indonesia like Batak Karo people from Sumatera island [7], Dayak Seberuang people in West Kalimantan [8], Kaili Inde people in Central Sulawesi [2], up to Eastern islands, namely Sasak people in West Nusa Tenggara [9] and Yali people in West Papua [10]. Among the ethnic groups across Indonesia, these people utilize the plants derived from the same families, making these families group of plants the "hot" repositories for new prospective natural drug discoveries. The similar utilization of plant types also enhances the safety, efficacy, and effectivity of these plants, as they produce the same after effect, which is to cure similar health problems. Although many plants are highly potential as the new natural drug resources, the need to assess their efficacy, effectivity, and safety must be ensured through numerous trials.

In this paper, we accentuate some potent plant candidates for drug developments that have undergone preliminary research, the understudied areas in Indonesia for novel exploration in natural drug discovery, also recommendations to accelerate the time-consuming natural drug bioprospecting. 


\section{METHODS}

Information on ethnobotany and ethnomedicinal research were conjoined from at least 20 research publications across Indonesia. We compiled the potent plants based on their frequent use in many places throughout Indonesia with the same believed medicinal properties. Then, we checked and chose the plants based on the list of Clinical Based Herbal Medicine (phytopharmaca) and ScienceBased Herbal Medicine (Obat Herbal Terstandar, OHT) from BPOM, also their empirical research data through various trials, such as clinically trialed and approved drugs.

\section{RESULTS AND DISCUSSION}

\section{Ethnomedicinal Research Across Indonesia}

Currently, there are approximately 200 ethnic groups dispersed within 13.000 islands in Indonesia [11,12]. These people adapt to their environment, employing the plants for diverse purposes. The practice of traditional healing exploiting the available surrounding plants has been done from ancient times. Indonesia alone employs not less than 30 thousand species of plants as traditional medication [13]. Most of the plants are also cultivated outside Indonesia but may differ in phytochemical properties and concentration as they lived in unrelated nature, consequently affecting their therapeutic abilities.

Plants produce primary and secondary metabolites which are fundamentals for their lives. Secondary metabolites production can be affected by the external forces, with more unique properties than the primary metabolites. These secondary metabolites provide the bioactive properties for natural drugs, such as carbohydrates, lipids, proteins, and their derivatives, also other classes of substances including alkaloids, phenols, terpenoids and acetogenins. Each of these substances has its own bioactivity in various systems [14].

We chose these potential medicinal plant candidates in Table 1 based on their frequent use, either with similar or dissimilar therapeutic purposes. This basis helps us invalidating their safety and availability across Indonesia as they are used by diverse ethnic groups throughout Indonesia. Further, we also sorted them out with clinically approved medicinal plants (phytopharmaca) and sciencebased herbal medicines (OHT) to explore the other potential medicinal plants, besides the heavily commercialized ones. We found 11 species of plants from 10 families that are employed in at least 5 areas across Indonesia, either with similar or different purposes.

Table 1. Medicinal plants used in more than five places across Indonesia under various purposes

\begin{tabular}{|c|c|c|c|c|}
\hline \multicolumn{5}{|c|}{ Medicinal plants used in more than 5 places across Indonesia } \\
\hline Families & Species & Vernacular name & Places & Uses \\
\hline Acanthaceae & $\begin{array}{l}\text { Graptophyllum } \\
\text { pictum }\end{array}$ & $\begin{array}{l}\text { Daun Ungu, } \\
\text { Daun Wungu } \\
\text { (Java) }\end{array}$ & $\begin{array}{l}\text { Jambi, Sumatera | Halmahera island | North } \\
\text { sumatera | Lombok, NTB | Central Sulawesi } \\
\text { | Sumbawa, NTB }\end{array}$ & $\begin{array}{l}\text { Back pain, fever, headache, after birth, } \\
\text { digestive problem, haemorrhoid and } \\
\text { diuretic }\end{array}$ \\
\hline Acoraceae & $\begin{array}{l}\text { Acorus } \\
\text { calamus }\end{array}$ & $\begin{array}{l}\text { Jeringau, Dlingo } \\
\text { (Java) }\end{array}$ & $\begin{array}{l}\text { Serampas, Jambi, Sumatera | Yogyakarta } \mid \\
\text { North Sumatera | Central Sulawesi } \mid \\
\text { Tengger, Jawa Timur }\end{array}$ & $\begin{array}{l}\text { Rheumatic, stomachache, tonic, fever, } \\
\text { cough and diarrhea }\end{array}$ \\
\hline $\begin{array}{l}\text { Amaryllidacea } \\
\text { e }\end{array}$ & Allium sativum & Bawang putih & $\begin{array}{l}\text { Serampas, Jambi, Sumatera | Yogyakarta } \mid \\
\text { North Sumatera } \mid \text { Central Sulawesi } \mid \\
\text { Tengger, Jawa Timur }\end{array}$ & $\begin{array}{l}\text { Headache, rheumatic, cholesterol, } \\
\text { fever, toothache and ulcer }\end{array}$ \\
\hline \multirow[t]{2}{*}{ Arecaceae } & Areca catechu & Pinang & $\begin{array}{l}\text { Serampas, Jambi, Sumatera } \mid \text { East } \\
\text { Kalimantan | Halmahera island } \mid \text { North } \\
\text { Sumatera | Sumbawa, NTB | Riau }\end{array}$ & $\begin{array}{l}\text { Injury, malaria, toothache, skin burn, } \\
\text { tonic, after birth and worm infection }\end{array}$ \\
\hline & Cocos nucifera & Kelapa hijau (ijo) & $\begin{array}{l}\text { Serampas, Jambi, Sumatera } \mid \text { Yogyakarta } \mid \\
\text { Halmahera island } \mid \text { North Sumatera } \mid \\
\text { Sumbawa, NTB }\end{array}$ & $\begin{array}{l}\text { Back pain, nerve problem, tonic, food } \\
\text { poisoning, fever and smallpox }\end{array}$ \\
\hline Compositae & $\begin{array}{l}\text { Ageratum } \\
\text { conyzoides }\end{array}$ & $\begin{array}{l}\text { Amis Kambing, } \\
\text { Babandotan } \\
\text { (Sundanese) }\end{array}$ & $\begin{array}{l}\text { Serampas, Jambi, Sumatera } \mid \text { Yogyakarta } \mid \\
\text { Halmahera island } \mid \text { Lombok, NTB } \mid \text { Central } \\
\text { Sulawesi| Riau }\end{array}$ & Injury, swelling, cough and cold \\
\hline Euphorbiaceae & $\begin{array}{l}\text { Aleurites } \\
\text { moluccanus }\end{array}$ & Kemiri & $\begin{array}{l}\text { Serampas, Jambi, Sumatera | East } \\
\text { Kalimantan | North Sumatera | Lombok, } \\
\text { NTB | Central Sulawesi | Sumbawa, NTB | } \\
\text { Minahasa, North Sulawesi }\end{array}$ & $\begin{array}{l}\text { Swelling, malaria, appetite, abscess, } \\
\text { anti-bleeding, injury and cancer }\end{array}$ \\
\hline Lamiaceae & Vitex trifolia & Legundi & $\begin{array}{l}\text { Serampas, Jambi, Sumatera | Yogyakarta } \mid \\
\text { North Sumatera | Lombok, NTB | Guguak } \\
\text { Sarai, West Sumatera }\end{array}$ & Itchy, give birth and cold \\
\hline Piperaceae & Piper betle & $\begin{array}{l}\text { Sirih, Sirih } \\
\text { Merah }\end{array}$ & $\begin{array}{l}\text { Serampas, Jambi, Sumatera | Yogyakarta } \mid \\
\text { Halmahera island | North Sumatera } \mid \\
\text { Lombok, NTB | Central Sulawesi | } \\
\text { Sumbawa, NTB | Minahasa, North Sulawesi }\end{array}$ & $\begin{array}{l}\text { Eye problem, fluor albus, cough, body } \\
\text { odour, skin burn, fever, antiseptic, } \\
\text { dental care, after birth and respiratory } \\
\text { problem }\end{array}$ \\
\hline Poaceae & $\begin{array}{l}\text { Saccharum } \\
\text { officinarum }\end{array}$ & Tebu & $\begin{array}{l}\text { Serampas, Jambi, Sumatera } \mid \text { Yogyakarta } \mid \\
\text { Halmahera island } \mid \text { West Papua } \mid \text { Guguak } \\
\text { sarai, West Sumatera }\end{array}$ & $\begin{array}{l}\text { Fever, kidney problem, eye problem, } \\
\text { flu, stomachache and cough }\end{array}$ \\
\hline
\end{tabular}


Many vernacular names available for Graptophyllum pictum, depending on their growth areas, for example, Daun wungu, pudding leaves in Jambi Sumatera [15], leleko in North Maluku (Halmahera Island) [5], and sate ati in Sumbawa, West Nusa Tenggara [16]. This plant can be utilized for health problems such as haemorrhoid, antiinflammatory [17,18], antimicrobial for Streptococcus sp. [19], antioxidant [20], a hepatoprotective agent in rats [21], antidiabetic in mice [22] and antifertility [23]. Indonesian particularly use this plant to alleviate hemorrhoid problem by drinking their leaves' boiled water with a maximum of 7 leaves per day. Cautions for pregnant and lactating mothers, also children were stated [18]. Study about the chemical constituents in this species showed the presence of flavonoids, steroids, tannins, coumarins, saponins, anthraquinones, phenols, and carbohydrates [24]. The leaves of this plant have anthocyanins pigment besides chlorophyll, enabling them to have a purplish colour and desired as ornamentals [25].

Acorus calamus with their local name Jeringau or Dlingo (Javanese), are perennial herb with diverse distribution around the world. This herb has $\alpha$ - and $\beta$-asarone, phenylpropanoids, lignans, terpenoids, alkaloids, flavonoids, quinones, sterols, and many derivatives mostly in their rhizomes [26]. These phytochemical substances have the ability as antimicrobial and anticancer [27], in vitro tested antidiabetic [28], antioxidant [29], larvicidal [30], insecticides [31] also as antivirals for dengue [32]. This plant is one of the most used medicinal plants across Indonesia, with 104 ethnic groups known to utilize this species [33].

Bawang putih or garlic (Allium sativum) has been immensely used as spices by Indonesian people, in fact, this species also holds a vast number of medicinal properties. This species was found to have the ability to lower cholesterol in eggs [34], also as antidiabetic and lowering lipid in humans (clinically trialed) [35]. This plant contains sulphuric compounds, proteins and minerals, also allicin which has the ability as antimicrobials [14,36]. Other secondary metabolites, including flavonoids, phenols, terpenoids, and alkaloids are also present in this species [37]. Indonesian people consume this plant by directly chew on them or employ them as cooking material [18]

This species of Arecaceae member called (Areca catechu) pinang have various medicinal properties in Indonesia. Several studies have proven their therapeutic properties as antidiabetic agent [38], insecticide against Coptotermes gestroi [39], antilipidemic [40], antimicrobial against $C$. albicans [41], also anthelmintic in chicken (pre-clinical study) [42]. Besides rich in lipids, this plant also comprised of alkaloids, carbohydrates, glycosides, phenols, flavonoids, and saponins in hydro alcoholic extracts [41]

Cocos nucifera a member of the Arecaceae family has so many uses to cure diverse health problems around the world including Indonesia. Other than its medicinal properties, Kelapa Hijau or ijo are also interestingly applied as furniture, construction material, ornamentals, food, also fertilizers [43]. The chemical constituent in this species are known to be alkaloids, saponins, glycosides, quinones, terpenoids, tannins, flavonoids, phenols, proteins [44], vitamin C, catechin, lauric acid, and L-arginine [45]. Kelapa, its vernacular name in Indonesia, exhibit the ability as antimalarial against $P$. berghei by in vivo testing in mice (pre-clinical study) [46], antioxidant activity [47], in vivo in pregnant women as preventive agent against morning sickness [48], skin problems reliever [18], also as antidiarrhea tested in vivo using mice (pre-clinical study) [49].

Ageratum conyzoides are seasonal plants with the characteristic of fishy smells if wilted. They are also known as Babandotan (Sundanese) and Amis Kambing or fishy goat in English, although some places might have their own vernacular names. This plant has been extensively used for injuries in several places in Indonesia, including Jambi [15], Bogor [50], and North Maluku [5]. They can also be utilized as antibacterial against Salmonella sp. [51], rheumatoid arthritis in mice (preclinical) [52], antifungal [53], stress reducer in koi fishes [54], herbicide against weed Cyperus rotundus [55], anticancer in HeLa cells (in vitro) [56] also antidiabetic property in mice [57]. Phytochemical studies were validating the presence of saponins, alkaloids, steroids, flavonoids, phenols, tannins [58], also various essential oils in the class of Terpenes, Coumarins, and Chromeno [54]. Although this plant is also classified as weeds but the therapeutic ability exerted can outcompete and even benefit them in cultivation for medicinal purposes.

Kemiri or candlenut (Aleurites moluccana) is a species member of Euphorbiaceae family and has been used in Indonesia or internationally as food spice or condiment, dye material and medicine materials that mainly employing from their seeds [50]. In several places across Indonesia, ethnic groups utilize this plant for various purposes. This plant possesses the antimicrobial activity against $S$. typhi, Vibrio cholera, and E. coli [59], lowering cholesterols and lipid absorption [60], anti-inflammatory and antipyretic [61], also as an analgesic [62]. The plant constituent is dominated by the oil which consists of 50 compounds, i.e. hexanoic acid and 7,10-Hexadecadienoic acid, methyl ester [63], while the seed contains 9 compounds that are classified as acids [64]. The bark of this plant consists of alkaloid, flavonoid, polyphenol, quinone, tannin, and terpenoids [65].

Legundi is a member of Verbenaceae family with the scientifically approved name, Vitex trifolia. They are often used as decoration plants whilst exhibiting medicinal properties from their chemical constituents. Those medicinal properties include anti-inflammatory agent [66], hepatoprotective agent [67], larvicidal [68], healing property for skin injuries [69], also studied for their ability as an anticancer agent [70]. This species contains several chemical compounds including diterpenes, namely rotundifuran, dihydrosolidagenone, abietatriene $3 \beta$-ol, also vitetrifolin A, B, C [71].

Piper betle or generally known as Sirih or Sirih Merah in Bahasa, are vine species of plant with uniquely heartshaped leaf. The Indonesian people, especially elders like to chew on them, which in turn strengthens their teeth. They optimally live in humid areas with good soils, such 
us Indonesian tropical forests [72]. Indonesians use this plant as one of their traditional healing materials for several purposes, which some of the uses, namely sore throat and antiseptic are consistent with Indonesian Ministry of Health's report in Formularies of Indonesian Traditional Medicinal Plants (FROTI). In the accepted formularies [18], Indonesians utilize this plant's healing properties by gargling the water used for boiling their leaves. The species' leaves contain numerous phytochemicals including alkaloid, phenol, flavonoid, tannins, saponins, terpenoids, steroids, also glycosides that each of them has therapeutic properties [73,74]. One of the constituent phenols are effectively inhibit bacterial infections by binding between the carboxyl group of phenols and proteins from bacteria. Up to date, many studies have been conducted invalidating their therapeutic properties such as antibacterial [73], antimalarial [75], antifungal [76], anti-inflammatory and antioxidant [77], also skin problems [78]. Other than its medicinal properties, this species is extensively used by many ethnic groups in Indonesia as their important rituals' material [79-81].

Saccharum officinarum or tebu (sugarcane) is a valuable commodity in Indonesia by encompassing many purposes in food, industry, medicine, even furniture from its residues (bagasse, designboom ${ }^{\circledR}$ ). Indonesia alone produces this commodity up to 2.19 million tonnes and production area with around 420 thousand hectares in 2017 [82]. This species has many believed healing purposes by ethnic groups across Indonesia, as described in Table 1. They are comprised of phenols, flavonoids, phytosterols, and triterpenoids [83]. They act as an antioxidant [84] and anti-inflammatory agent [85], a hepatoprotective agent in rats [86], antimicrobial activity against $E$. coli and $P$. aeruginosa [87], immunomodulator in chicken [88], also an antifertility agent in rats [89].

Laos or lengkuas is a common cooking condiment employed by housewives throughout Indonesia. Alpinia galanga is a herbaceous plant which its rhizomes are widely used in medication, industries, and nutritious fields. They prefer warm places with high humidity for optimum growth and development [90]. They exhibit inhibiting activity against bacteria in fish preservation [91], antidiabetic property in rabbits [92], immunostimulant property [93], preventing stomachache [94], even inhibiting leishmanial parasites (in vitro) [95]. Components from this plant include $\beta$-bisabolene, $(\mathrm{E})-\beta$ farnesene, (E,E)-farnesyl acetate, $(\mathrm{Z}, \mathrm{E})$ - farnesol, $\beta$ caryophyllene from terpenoids class, as the major constituent. Other than that, numerous constituents numbering up to 60 compounds were observed in the study of A. galanga's extracts [96].

The plants described before were chosen as they exhibit many medicinal properties either in vitro, preclinically, or clinically tested in humans. Some of the data were in concordance with the ethnic groups' beliefs of their medicinal properties. Most of the data collected were dominated by in vitro studies, while some therapeutic beliefs haven't been scientifically tested. This is the gap that we scientists can fulfil by providing scientific data for further developments of these potential medicinal plants. The development of these plants may enhance the conservation of these plants and therapeutic alternatives.

\section{Strategical Approaches to Accelerate the Bioprospecting of Novel Natural Drugs}

Advancements in molecular technology will enable the researcher to integrate the use of phylogenetic, -omics approaches, DNA barcoding, and Global Biodiversity Information Facility (GBIF) to aid in the bioprospecting of novel natural drugs from medicinal plants. Studies that assessed the conserved orthologous gene of serine carboxypeptidase-like (SCPL) in the cross-species analysis were found in several plants were conducted. This SCPL gene plays a role in natural product construction which has the importance in plant defense [97,98]. The studies conducted using genomic and metabolomics disciplines to uncover the orthologous gene placement in cross-species' genome, may alleviate the number of 'hits' in ethnomedicinal studies.

Table 2. List of families and its genus representatives that are considered as hot nodes $[99,100]$

\begin{tabular}{|l|l|}
\hline \multicolumn{2}{|c|}{ Hot nodes for bioactive constituent } \\
\hline Eumily & \multicolumn{1}{c|}{ Genus } \\
\hline Fabaceae & Aleurites $\mathrm{sp}$. \\
\hline Asteraceae & Acrocarpus $\mathrm{sp}$. \\
\hline Malvaceae & Myriactis $\mathrm{sp}$. \\
\hline Anacardiaceae & Abroma $\mathrm{sp}$. \\
\hline Melastomataceae & Anacardium $\mathrm{sp}$. \\
\hline & Medinilla $\mathrm{sp}$. \\
\hline
\end{tabular}

The molecular technology facilitates the study of underlying mechanisms on how these plants produce the desired substances, as well as identification of plants which have the most advantageous compounds' properties. The plants can produce the desired compounds because of evolution and adaptation to their surroundings. The production of these metabolites may support them in their survival against pathogens, climate change, or other substances that deter their life expectancy. As they evolved from the same basal organism, these groups of medicinal plants in one family or genus may have the same genes needed that code the desired substances [101, 102]. The assessment of rich bioactive-encompassed plants was done, resulting in various plants classified into family level groupings. Tens of families were obtained in different approaches $[99,100]$. These family groups are very potential for future bioprospecting as they were found to be bio actively rich plants. Examples of these families were given in Table 2. By that properties, natural drug discovery can be accelerated by a more focused approach, combined with DNA barcoding, these compelling technologies provide an accurate and precise screening of potent medicinal plants. 

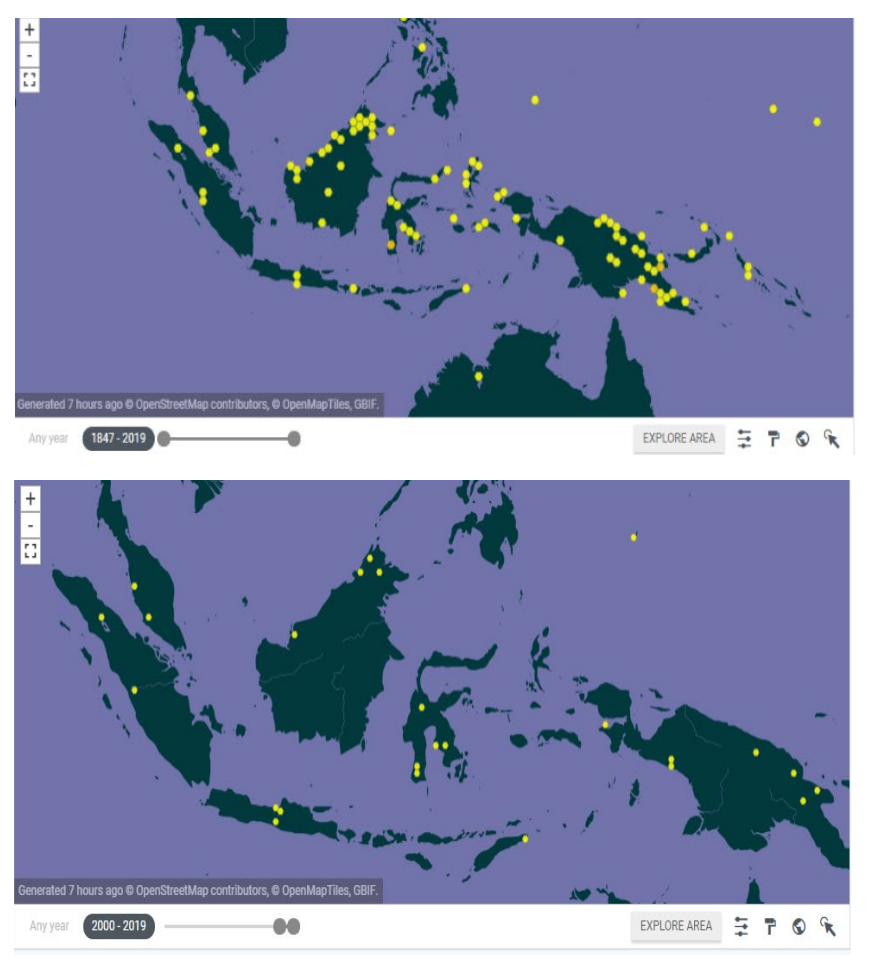

Figure 1. The distribution map of Piper betle (Sirih Merah) in Indonesia in the year 1847 (upper) and 2000 (below) based on GBIF.

Plants are prone to environmental cues that could impede their lives. Comparable to any other living things, plants can adapt to a certain environment and maintain their survival, either by modifying their physical structures or producing metabolites that hinder the predators or pathogens $[103,104]$. These metabolites that they produce can also be useful for humans as we might face the same kind of pathogens. Understanding the ecological repercussions to these plants will enable us to once again precisely and accurately predict the potent medicinal plants. Enhanced by the improving geographical information system (GIS) such as GBIF [105], the researcher can map the distribution and pinpoint the areas with a high occurrence of medicinal plants. An example of Piper betle distribution's mapping with GBIF in Figure 1 showed the decrease of occurrence of this species. The decreasing number of occurrences might be caused by little conservation or recording efforts. Although the implementation of this technology is still inadequate, but it possesses significant support in natural drug discovery through an ecological approach.

Based on the exploration of ethnomedicinal studies across Indonesia, the studies were mainly stressed in Java, Bali, Sumatera, Sulawesi, and Kalimantan islands, demonstrated by a vast amount of data of ethnomedicinal studies found. Although encompassed in the mentioned islands, some parts within the islands still have a scarce number of ethnomedicinal studies. Little data on the eastern part of Indonesian particularly in ethnomedicinal studies was observed. Combined with the fact of lifting the local people's quality of lives, places, ethnic groups, and cities of
West and East Nusa Tenggara also Papua provinces are potential for future studies. Even though there are several ethnomedicinal studies, but the low number of studies can be correlated with low number of areal coverage of studies from these provinces, conjoined with the fact of many dispersed ethnic groups within these provinces, enhancing their potential as new research area notably in ethnomedicinal studies. The approach based on combing the ethnic groups is also plausible to be done, in view of the fact that Indonesia is a repository for hundreds of ethnic groups.

\section{CONCLUSION}

A total of 11 potential plants from 10 families are accentuated as potential medicinal plants to be explored in the future were presented. Three Provinces in Indonesia for further studies in ethnomedicinal areas were also described. These plants and areas are gaps to be fulfilled, which can be studied further for their pharmacology and potentials in many sectors such as research institutes and industries. Confronting a large amount of medicinal plant data, highthroughput screening methods such as -omics technologies, Bioactivity-guided prospecting and bioinformatics can provide a more efficient process in natural drug exploration and conservation strategies. A combination of these technologies will empower us in hastened bioprospecting of natural drugs from medicinal plants, particularly in the hot nodes within the phylogeny tree.

\section{ACKNOWLEDGMENT}

The completed review would not be possible without the supports from Ristekdikti-NERC Newton Fund Wallacea Program for the funding of this research and publication.

\section{REFERENCES}

[1] Nugraha, A. S. \& P. A. Keller, 2011. Revealing Indigenous Indonesian Traditional Medicine: AntiInfective Agents. Natural Product Communications, 6(12), pp. 1953-66.

[2] Fathurrahman, F., J. Nursanto, A. Madjid \& R. Ramadanil, 2016. Ethnobotanical Study of Kaili Inde Tribe in Central Sulawesi Indonesia. Emirates Journal of Feed and Agriculture, 28(5), pp. 337 47.

[3] Walujo, E. B., 2008. Review: Research Ethnobotany in Indonesia and the Future Perspectives. Biodiversitas, 9(1), pp. 59-63.

[4] Mitra, Robin, Brad Mitchell, Chris Gray, John Orbell, Tony Coulepis \& Morley Somasundaram Muralitharan, 2007. Medicinal Plants of Indonesia. $A P B N, 11(11)$, pp. 726-43.

[5] Tamalene, M. N., M. H. I. Al-Muhdhar, E. Suarsini \& F. Rohman, 2016. Study of Ethnobotany of Medicinal Plant of Tobelo Dalam (Togutil) Ethnic Group of Halmahera Island, Indonesia. Medicinal Plants, 8(2), pp. 127-36.

[6] Torri, M. C., 2012. The JAMU System in Indonesia: Linking Small-Scale Enterprises, Traditional Knowledge and Social Empowerment among Women in Indonesia. Journal of International Women's Studies, 13(1), pp. 32-45. 
[7] Purba, E. C., Nisyawati \& M. Silalahi, 2016. The Ethnomedicine of the Batak Karo People of Merdeka Sub-District, North Sumatra, Indonesia. International Journal of Biological Research, 4(2), pp. 181-9.

[8] Setiawan, H., L. Hakim \& J. Batoro, 2015. Ethnobotany of Nepenthes spp. in Dayak Seberuang People, West Kalimantan, Indonesia. Journal of Biodiversity and Environmental Sciences, 7(6), pp. 275-84.

[9] Rahayu, M., H. Rustiami \& Rugayah, 2016. Ethnobotanical Study of Sasak Ethnic, East Lombok, West Nusa Tenggara. Journal of Tropical Biology and Conservation, Volume 13, pp. 85-99.

[10] Milliken, W., 2000. Ethnobotany of the Yali. Edinburgh: Royal Botanic Garden.

[11] Kemlu, n.d. Embassy of the Republic of Indonesia Paris France. [Online] Available at: https://kemlu.go.id/paris/en/pages/informasi umum /638/etc-menu [Accessed 20 August 2019].

[12] Pandiangan, D., M. Silalahi, F. Dapas \& F. Kandou, 2019. Diversity of medicinal plants and their uses by the Sanger tribe of Sangihe Islands, North Sulawesi, Indonesia. Biodiversitas, 20(2), pp. 611-21.

[13] TREDA, 2009. Indonesian Herbal: The Traditional Therapy. 1st ed. Jakarta: Trade Research and Development Agency, Ministry of Trade, Republic of Indonesia.

[14] de Padua, L., Bunyapraphatsara, N. \& Lemmens, R., 1999. Plant Resources of South-East Asia No12(1). Medicinal Plant and poisonous plants 1. Leiden: Backhuys.

[15] Hariyadi, B. \& T. Ticktin, 2012. Uras: Medicinal and Ritual Plants of Serampas, Jambi Indonesia. Ethnobotany Research and Applications, Volume 2012, pp. 133-49.

[16] Rahayu, M. \& H. Rustiami, 2017. Etnobotani Masyarakat Samawa Pulau Sumbawa. Scripta Biologica, 4(4), pp. 235-45.

[17] Sya'haya, S. \& R. N. Iyos, 2016. Pengaruh Pemberian Ekstrak Daun Ungu (Graptophylum pictum Griff) terhadap Penyembuhan Hemoroid. Majority, 5(5), pp. 155-60.

[18] Menkes, 2017. Formularium Ramuan Obat Tradisional Indonesia, Jakarta: Kementerian Kesehatan Republik Indonesia.

[19] Nisa, T. H. \& T. P. D. Prakoso, 2017. Inhibition of Streptococcus Mutant Growth by Purple Leaf Extract (Graptophyllum pictum). Proceeding International Seminar of Occupational Health and Medical Sciences (I-SOCMED) 2017, pp. 162-7.

[20] Rustini, N. L., 2018. Identification of Active Antioxidant Compounds from Ungu Leaf Ethanol Extract (Graptophyllum pictum L. Griff). Journal of Health Sciences and Medicine, 2(1).

[21] Goswami, M. \& H. Maurya, 2016. Pharmacological investigations of Graptophyllum pictum as hepatoprotective potential in albino rats. Int. J. Rec. Adv. Sci. Tech., 3(4), pp. 1-11.

[22] Olagbende-Dada, S., S. Ogbonnia, H. Coker \& G. Ukpo, 2011. Blood glucose lowering effect of aqueous extract of Graptophyllum pictum (Linn) Griff. on alloxan-induced diabetic rats and its acute toxicity in mice. African Journal of Biotechnology, 10(6), pp. 1039-43.

[23] Olagbende-Dada, S., G. Ukpo, H. Coker \& S. Adesina, 2009. Oxytocic and anti-implantation activities of the leaf extracts of Graptophyllum pictum (Linn.) Griff. (Acanthaceae). African Journal of Biotechnology, 8(21), pp. 5979-84'.

[24] Jiangseubchatveera, N., A. Teerawutgulrag, D. Santiarworn \& S. G. Pyne, 2017. Phytochemical screening, phenolic and flavonoid contents, antioxidant and cytotoxic activities of Graptophyllum pictum (L.) Grif. Chiang Mai Journal of Science, 44(1), pp. 193-202.

[25] Rosmala, A., N. Khumaida \& D. Sukma, 2016. Alteration of Leaf Anatomy of Handeuleum (Graptophyllum pictum L. Griff) due to Gamma Irradiation. HAYATI Journal of Biosciences, 23(3), pp. 138-42.

[26] Feng, Xiao-Lin, Yang Yu, Da-Peng Qin, Hao Gao, Xin-Sheng Yao, 2013. Acorus Linnaeus: A review of traditional uses, phytochemistry and neuropharmacology. RSC Advances, Volume 7, pp. $1-10$.

[27] Syarif, R. A., R. Rasyid \& A. Najib, 2015. Dringo rhizome (Acorus calamus L.): A potential source high $\beta$-asarone. Journal of Chemical and Pharmaceutical Research, 7(3), pp. 258-61.

[28] Zhou, Chang Xin, Di Qiao, You You Yan, Hao Shu Wu, Jian Xia Mo \& Li She Gan, 2012. A new anti-diabetic sesquiterpenoid from Acorus calamus. Chinese Chemical Letters, 23(10), pp. 1165-8.

[29] Parki, Archana, Pinky Chaubey, Om Prakash, Ravendra Kumar \& Anil K. Pant, 2017. Seasonal variation in essential oil compositions and antioxidant properties of Acorus calamus L. accessions. Medicines, Volume 4.

[30] Sulaiman, S., D. A. Kamarudin \& H. Othman, 2008. Evaluation of Bifenthrin and Acorus calamus Linn. Extract against Aedes aegypti L. and Aedes albopictus (Skuse). Iranian J. Athropod-Borne Dis., 2(2), pp. 7-11.

[31] Nitbani, F. O., L. Kadang \& C. D. Bulin, 2012. The Essential Oils from Rhizome Extracts of Acorus Calamus L. Are Potential Herbal Insecticide against Plutella Xylostella L. Pests. Journal of Applied Chemical Science, 1(1), pp. 9-18.

[32] Rosmalena, Berna Elya, Beti E. Dewi, Fithriyah, Hidayati Desti, Marissa Angelina, Muhammad Hanafi, Puspa D. Lotulung, Vivitri D. Prasasty \& Dimas Seto, 2019. The Antiviral Effect of Indonesian Medicinal Plant Extracts Against Dengue Virus In Vitro and In Silico. Pathogens, $8(2)$, p. 85

[33] Subositi, D., R. Mujahid \& Y. Widiyastuti, 2015. Keragaman Genetik Dringo (Acorus calamus L.) berdasarkan Inter-Simple Sequence Repeats (ISSR). Buletin Kebun Raya, 18(2), pp. 125-34.

[34] Bidura, I. G. N. G., I. B. G. Partama, B. R. T. Putri \& N. L. Watiniasih, 2017. Effect of Water Extract of Two Leaves (Allium sativum and Sauropus androgynus) on Egg Production and Yolk Cholesterol Levels in Egg Laying Hens. Pakistan Journal of Nutrition, 16(7), pp. 482-7.

[35] Sukandar, E.Y., H. Permana, I.K. Adnyana, J.I Sigit, R.A. Ilyas, P. Hasimun \& D. Mardiyah, 2010. Clinical Study of Turmeric (Curcuma longa L.) and Garlic (Allium sativum L.) Extracts as Antihyperglycemic and Antihyperlipidemic Agent in Type-2 Diabetes-Dyslipidemia Patients. International Journal of Pharmacology, 6(4), pp. 456-63.

[36] Sivananthan, M., 2013. Pharmacological activities of Andrographis paniculata, Allium sativum and 
Adhatoda vasica. International Journal of Biomolecules and Biomedicine (IJBB), 3(2), pp. 13-20.

[37] Priska, M., N. Peni \& L. Carvallo, 2019. Phytochemicals Screening and Antioxidant Effectiveness of Garlic (Allium sativum) from Timor Island. Biosaintifika, 11(1), pp. 1-7.

[38] Akhter, Shirin, Maruf Hassan, Shahnaz Rahman, Afifa Sultana, Shejuty Shahreen \& Joyonta Banik, 2014. Anti-hyperglycemic activity studies on leaves and stems of Areca catechu L. (Arecaceae). Advances in Natural and Applied Sciences, 8(4).

[39] Tarmadi, D., K. H. Setiawan, M. Ismayati \& S. Yusuf, 2009. The Effication of Areca catechu L Kernel extract against Subterranean Termite Coptotermes gestroi. Wood Entomology and Preservation - The First International Symposium of IWRS, pp. 212-5.

[40] Bhat, S. K., M. Sarpangala \& D. Ashwin, 2017. Antilipidemic activity of arecanut, Areca catechu L.: A valuable herbal medicine. International Journal of Herbal Medicine, 5(1), pp. 35-8.

[41] Pahadia, A., R. Gawde \& S. Agrawal, 2013. Antimicrobial activity of hydro alcoholic extract of Areca catechu. International Journal of Pharmaceutical Erudition, 3(1), pp. 18-25.

[42] Muboarokah, W. W., W. Nurcahyo, J. Prastowo \& K. Kurniasih, 2019. In vitro and in vivo Areca catechu crude aqueous extract as an anthelmintic against Ascaridia galli infection in chickens. Veterinary World, 12(6), pp. 877-82.

[43] Lima, E.B.C., C.N.S. Sousa, L.N. Meneses, N.C. Ximenes, M.A. Santos Junior, G.S. Vasconcelos, N.B.C. Lima, M.C.A. Patrocinio, D. Macedo \& S.M.M. Vasconcelos, 2015. Cocos nucifera (L.) (Arecaceae): A phytochemical and pharmacological review. Braz J Med Biol Res, 48(11).

[44] Pritha, S. D. S. J. \& S. Karpagam, 2017. Evaluation of phytochemical content of Coconut Shell Oil. National Journal of Advanced Research, 3(2), pp. $1-2$.

[45] Roopan, S. M., 2016. An Overview of Phytoconstituents, Biotechnological Applications, and Nutritive Aspects of Coconut (Cocos nucifera). Appl Biochem Biotechnol, 179(8), pp. 1309-24.

[46] Al-Adhroey, Abdulelah H., Zurainee M. Nor, Hesham M. Al-Mekhlafi, Adel A. Amran \& Rohela Mahmud,2011. Evaluation of the use of Cocos nucifera as antimalarial remedy in Malaysian Folk Medicine. Journal of Ethnopharmacology, Volume 134, pp. 988-91.

[47] Kalina, S. \& S. Navaratne, 2019. Antibacterial Potential Of Root And Bark Of Cocos Nucifera Linn. Against Isolated Urinary Tract Infection Causing Pathogens. International Journal of Food Science, Volume 2019.

[48] Ariestini, T. R. \& W. Purnomo, 2018. The Effect of Young Coconut Water against Morning Sickness among Women in the First Trimester of Pregnancy.. Indian Journal of Public Health Research \& Development, 9(11), pp. 1729-33.

[49] G.D., Edem, Ekanem Au \& C.C. Mbadugha, 2016. Ameliorating effect of coconut water on the epithelium and gastric goblet cells of albino wistar rats induced with castor oil. International Journal of Biology Research, 1(4), pp. 22-8.

[50] Heyne, K., 1987. Tumbuhan Berguna Indonesia. 3rd ed. Jakarta: Yayasan Sarana Wana Jaya.
[51] Ajayi, O.E., S.I. Awala, F.N. Okogbue, A.G. Ogunleye, B.F. Olaleye, 2016. Antibacterial Efficacy of Ageratum conyzoides on Salmonella Species Isolated from Suspected Typhoid Fever Patients in Akure Metropolis, Nigeria. Journal of Advances in Medical and Pharmaceutical Sciences, $6(2)$.

[52] Harfiani, Erna, Riri Nurul Suci, Katrin Basah, Ade Arsianti, Anton Bahtiar, 2017. Functional Analysis of Ageratum conyzoides L. (Babandotan) Leaves Extract on Rheumatoid Arthritis Model Rat. Asian journal of Pharmaceutical and Clinical Research, 10(3), pp. 429-33.

[53] Yusnawan, E. \& A. Inayati, 2018. Antifungal Activity of Crude Extracts of Ageratum conyzoides, Cyperus rotundus, and Amaranthus spinosus Against Rust Disease. Journal of Agricultural Science, 40(3), pp. 403-14.

[54] Sulmartiwi, L., W. Darmanto \& M. A. Alamsjah, 2014. Stress Reducing Substance of Ageratum conyzoides and Its Application to Koi Carp (Cyprinus carpio) Transportation. Journal of Natural Sciences Research , 4(19), pp. 67-85.

[55] Hikmah, A. U., F. Bilkis, D. Maelani \& Triastinurmiatiningsih, 2018. Pemanfaatan Ekstrak Daun Babandotan (Ageratum conyzoides) sebagai Bioherbisida Gulma Rumput Teki (Cyperus Rotundus). Ekologia, 18(1), pp. 25-30.

[56] Febriansah, R., W. A. Lubis \& F. Fathurrahma, 2018. Potensi Ekstrak Etanolik Herba Bandotan (Ageratum conyzoides L.) sebagai Alternatif Agen Antikanker Serviks secara In Silico dan In Vitro. Jurnal Tumbuhan Obat Indonesia, 11(1), pp. 2533.

[57] Rahman, M. A., R. Sultana, R. Akter \& M. S., Islam, 2013. Antidiarrheal and antidiabetic effect of ethanol extract of whole Ageratum conyzoides L. in albino rat model. African Journal of Pharmacy and Pharmacology, 7(23), pp. 1537-45.

[58] Harjanti, D. W., R. Ciptaningtyas \& F. Wahyono, 2018. Phytochemical properties and antibacterial activity of Ageratum conyzoides, Piper betle, Muntinga calabura and Curcuma domestica against mastitis bacteria isolates. 1st International Conference of Animal Science and Technology (ICAST), Volume 247.

[59] Mukhriani, Asrul Haeria Ismail, Syamsuri Syakri \& Nurfitra Fadiyah, 2018. Identifikasi Golongan Senyawa Antibakteri Fraksi Polar dan Non Polar Kulit Batang Kemiri (Aleurites moluccana L. Willd) dengan Metode Bioautografi Kontak. JF FIK UINAM, 6(1), pp. 46-54.

[60] Pedrosa, R.C., C. Meyre-Silva, V. Cechinel-Filho, J.C. Benassi, L.F.S. Oliveira, V. Zancanaro, J. Dal Magro \& R.A. Yunes, 2002. Hypolipidaemic Activity of Methanol Extract of Aleurites moluccana. Phytotherapy Research, Volume 16, pp. 765-8.

[61] Niazi, J., V. Gupta, P. Chakarborty \& P. Kumar, 2010. Anti-inflammatory and antipyretic activity of aleuritis moluccana leaves. Asian Journal of Pharmaceutical and Clinical Research, 3(1), pp. 35-7.

[62] Quintao, Nara L., Christiane Meyre-Silva, Gislaine F. Silva, Carla S. Antonialli, Lilian W. Rocha, Ruth M. Lucinda-Silva, Angela Malheiros, Marcia M. Souza, Valdir Cechinel Filho \& Tania M.B., 2011. Aleurites moluccana (L.) Willd. Leaves: Mechanical Antinociceptive Properties of a 
Standardized Dried Extract and Its Chemical Markers. Evidence-Based Complementary and Alternative Medicine, Volume 2011.

[63] Siddique, Bazlul Mobin, Anees Ahmad, Abbas F.M. Alkarkhi, Mahamad Hakimi Ibrahim \& Mohd Omar K., 2011. Chemical Composition and Antioxidant Properties of Candlenut Oil Extracted by Supercritical CO2. Journal of Food Science, 76(4), pp. 535-42.

[64] Norulaini, Nik, Rahmad Setia Budi, Anuar Omar, Md Zaidul L. S. \& Mohd Omar A. K., 2004. Major Chemical Constituents of Candlenut Oil Extract Using Supercritical Carbon Dioxide. Malaysian Journal of Pharmaceutical Sciences, 2(1), pp. 6172.

[65] Windyaswari, A. S., F. Faramayuda \& A. Junita, 2016. Telaah Fitokimia Kulit Batang Kemiri (Aleurites moluccana L.). Seminar Nasional Farmasi (SNIFA) 2 Unjani, pp. 34-40.

[66] Matsui, Mariko, Shilpa Kumar-Roine, H. Taiana Darius, Mireille Chinain, Dominique Laurent \& Serge Pauillac, 2009. Characterisation of the antiinflammatory potential of Vitex trifolia L. (Labiatae), a multipurpose plant of the Pacific traditional medicine. Journal of Ethnopharmacology, 126(3), pp. 427-33.

[67] Manjunatha, B. \& S. Vidya, 2008. Hepatoprotective Activity of Vitex trifolia against Carbon Tetrachloride-induced Hepatic Damage. Indian J Pharm Sci, 70(2), pp. 241-5.

[68] B., Eka Cania \& Endah Setyaningrum, 2013. Uji Efektivitas Larvasida Ekstrak Daun Legundi (Vitex trifolia) terhadap Larva Aedes aegypti. Medical Journal of Lampung University, 2(4), pp. 52-60.

[69] Manjunatha, B.K., S.M. Vidya, V. Krishna, K.L. Mankani, S.D. Jagadeesh Singh \& Y.N. Manohara, 2007. Comparative evaluation of wound healing potency of Vitex trifolia L. and Vitex altissima L.. Phytotherapy Research, 21(5), pp. 457-61.

[70] Jose, B. E., S. Jebaseelan \& R. Meera, 2017. Phytochemical Investigation and Anti-Cancer Activity of Vitex trifolia. Journal of Pharmaceutical Sciences and Research, 9(7), pp. 1056-62.

[71] Meena, A.K., Uttam Singh, A.K. Yadav, B. Singh \& M.M. Rao, 2010. Pharmacological and Phytochemical Evidences for the Extracts from Plants of the Genus Vitex - A Review. International Journal of Pharmaceutical and Clinical Research, 2(1), pp. 1-9.

[72] Pradhan, D., K. Suri, D. Pradhan \& P. Biswasroy, 2013. Golden Heart of the Nature: Piper betle L.. Journal of Pharmacognosy and Phytochemistry, 1(6), pp. 147-67.

[73] Syahidah, A., C.R. Saad, M.D. Hassan, Y. Rukayadi, M.H. Norazian \& M.S. Kamarudin, 2017. Phytochemical Analysis, Identification and Quantification of Antibacterial Active Compounds in Betel Leaves, Piper betle Methanolic Extract. Pakistan Journal of Biological Sciences, Volume 20, pp. 70-81.

[74] Shetty, S. \& K. Vijayalaxmi, 2012. Phytochemical Investigation of Extract/ Solvent Fractions of Piper Nigrum Linn. Seeds and Piper Betle Linn. Leaves. International Journal of Pharma and Bio Sciences , 3(2), pp. 344-9.

[75] Al-Adhroey, Abdulelah H., Zurainee M. Nor, Hesham M. Al-Mekhlafi, Adel A. Amran \& Rohela Mahmud, 2011. Antimalarial Activity of
Methanolic Leaf Extract of Piper betle L. Molecules, Volume 16, pp. 107-18.

[76] Trakranrungsie, N., A. Chatchawanchonteera \& W. Khunkitti, 2008. Ethnoveterinary study for antidermatophytic activity of Piper betle, Alpinia galanga and Allium ascalonicum extracts in vitro. Research in Veterinary Science, Volume 84, pp. 80-4.

[77] Pin, K.Y., A. Luqman Chuah, A. Abdull Rashih, M.P. Mazura, J. Fadzureena, S. Vimala \& M.A. Rasadah, 2010. Antioxidant and Anti-Inflammatory Activities of Extracts of Betel Leaves (Piper Betle) from Solvents with Different Polarities. Journal of Tropical Forest Science, 22(4), pp. 448-55.

[78] Lien, Le Thin; Nguyen Thi Tho, Do Minh Ha, Pham Luong Hang, Nghia Phan Tuan \& Nguyen Dinh Thang, 2015. Influence of phytochemicals in piper betle linn leaf extract on wound healing. Burns \& Trauma, 3(23).

[79] Sujarwo, W. \& G. Caneva, 2016. Using quantitative indices to evaluate the cultural importance of food and nutraceutical plants: Comparative data from the Island of Bali (Indonesia). Journal of Cultural Heritage, Volume 18, pp. 342-8.

[80] Rahayu, M., E. S. Kuncari, H. Rustiami \& Ridwan, 2019. Diversity of plants and significance of nyiwaq ceremonies by Sasak ethnic, Lombok, West Nusa Tenggara. AIP Conference Proceedings, Volume 2120.

[81] Zulia, Z., J. Batoro \& B. Yanuwiadi, 2017. Ethnobiological Study of Larung Sembonyo Ceremony in Watulimo District, Trenggalek as a Basic of Ecotourism Planning. Journal of Indonesian Tourism and Development Studies, 5(1), pp. 49-56.

[82] BPS, 2017. Statistik Tebu Indonesia, Jakarta: Badan Pusat Statistik Indonesia .

[83] Feng, Simin, Zisheng Luo, Yanbing Zhang, Zhou Zhong \& Baiyi Lu, 2014. Phytochemical contents and antioxidant capacities of different parts of two sugarcane (Saccharum officinarum L.) cultivars. Food Chemistry, Volume 151, pp. 452-8.

[84] Elakkiya, S., R. Pallavi, S. S. R. Tennety \& Suganyadevi, 2012. To Evaluate In Vitro Antioxidant Property of Sugarcane (Saccharum officinarum L) Peel. International Journal of Pharma and Bio Sciences, 3(3), pp. 65-73.

[85] B., N. Ghiware, Aseemuddin N., Kawade R.M. \& Vadvalkar S. M., 2012. Pharmacological Exploration Of Saccharum officinarum Leave Extracts For Its Anti-Oxidant And AntiInflammatory Activity. International Journal of PharmTech Research, 4(4), pp. 1785-91.

[86] Patel, Bhavik A., Jignesh D. Patel, Bhuvan P. Raval, Tejal R. Gandhi, Kirti Patel \& Paresh U. Patel, 2010. Hepatoprotective activity of Saccharum officianarum against ethyl alcohol induced hepatotoxicity in rats. Der Pharmacia Lettre, 2(1), pp. 94-101.

[87] Uchenna, E. F., O. A. Adaeze \& A. C. Steve, 2015. Phytochemical and Antimicrobial Properties of the Aqueous Ethanolic Extract of Saccharum officinarum (Sugarcane) Bark. Journal of Agricultural Science, 7(10), pp. 291-7.

[88] Awais, M. M. \& M. Akhtar, 2012. Evaluation of Some Sugarcane (Saccharum officinarum L.) Extracts for Immunostimulatory and Growth 
Promoting Effects in Industrial Broiler Chickens. Pakistan Veterinary Journal, 32(3), pp. 398-402.

[89] Balamurugan, K., V. Kalaichelvan, G. Anuradha \& M. Gopal K., 2009. Antifertility Activity of Methanolic Extract of Saccharum officinarum Linn. (Leaves) on Female Albino Rats. International Journal of PharmTech Research , 1(4), pp. 1621-4.

[90] Brown, D., 1995. Encyclopedia of Herbs and Their Uses. London: Dorling Kindersley.

[91] Florensia, S., P. Dewi \& N. R. Utami, 2012. Pengaruh Ekstrak Lengkuas pada Perendaman Ikan Bandeng terhadap Jumlah Bakteri Pengaruh Ekstrak Lengkuas pada Perendaman Ikan Bandeng terhadap Jumlah Bakteri. Life Science Journal of Biology, 1(2), pp. 113-8.

[92] Akhtar, M. S., M. Khan \& M. Malik, 2002. Hypoglycaemic activity of Alpinia galanga rhizome and its. Fitoterapia, 73(7-8), pp. 623-8

[93] Bendjeddou, D., K. Lalaoui \& D. Satta, 2003. Immunostimulating activity of the hot watersoluble polysaccharide extracts of Anacyclus pyrethrum, Alpinia galanga and Citrullus colocynthis. Journal of Ethnopharmacology, 88(23), pp. 155-60.

[94] Matsuda, Hisashi, Yutana Pongpiriyadacha, Toshio Morikawa, Momotaro Ochi \& Masayuki Yoshikawa, 2003. Gastroprotective effects of phenylpropanoids from the rhizomes of Alpinia galanga in rats: structural requirements and mode of action. European Journal of Pharmacology, 471(1), pp. 59-67.

[95] Kaur, Amandeep, Ranvir Singh, Chinmoy Sankar Dey, Shyam Sundar Sharma, Kamlesh K. Bhutani \& Inder Pal Singh, 2010. Gastroprotective effects of phenylpropanoids from the rhizomes of Alpinia galanga in rats: structural requirements and mode of action. Gastroprotective effects of phenylpropanoids from the rhizomes of Alpinia galanga in rats: structural requirements and mode of action, Volume 48, pp. 314-7.

[96] Jantan, I. bin, F. b. Ahmad \& A. S. Ahmad, 2013. Constituents of the Rhizome and Seed Oils of Greater Galangal Alpinia galangal (L.) Willd. from Malaysia. Journal of Essential Oil Research, 16(3), pp. 174-6.

[97] Mugford, S. T. \& A. Osbourn, 2010. Evolution of serine carboxypeptidase-like acyltransferases in the monocots. Plant Signal Behav., 5(2), pp. 193-5.

[98] Tohge, Takayuki, Regina Wendenburg, Hirofumi Ishihara, Ryo Nakabayashi, Mutsumi Watanabe, Ronan Sulpice, Rainer Hoefgen, Hiromitsu Takayama, Kazuki Saito, Mark Stitt \& Alisdair R. Fernie, 2016. Characterization of a recently evolved flavonol-phenylacyltransferase gene provides signatures of natural light selection in Brassicaceae. Nature Communications, Volume 7.

[99] Saslis-Lagoudakis, C. Haris, Vincent Savolainen, Elizabeth M. Williamson, Felix Forest, Steven J. Wagstaff, Sushim R. Baral, Mark F. Watson, Colin A. Pendry \& Julie A. Hawkins, 2012. Phylogenies reveal predictive power of traditional medicine in bioprospecting. PNAS , 109(39), pp. 15835-40.

[100]Douwes, E., Crouch, N., Edwards, T. \& Mulholland, D., 2008. Regression analyses of southern African ethnomedicinal plants: informing the targeted selection of bioprospecting and pharmacological screening subjects. Journal of Ethnopharmacology, Volume 119, pp. 356-64.
[101]Garnatje, T., J. Penuelas \& J. Valles, 2017. Ethnobotany, Phylogeny, and 'Omics' for Human Health an Food Security. Cell Press, 22(3), pp. 187-91.

[102] Yessoufou, K., B. H. Daru \& A. M. Muasya, 2015. Phylogenetic Exploration of Commonly Used Medicinal Plants in South Africa. Molecular Ecology Resources, 15(2), pp. 405-13.Douwes, E. N. Crouch, T. Edwards \& D. Mulholland, 2008. Regression analyses of southern African ethnomedicinal plants: informing the targeted selection of bioprospecting and pharmacological screening subjects. Journal of Ethnopharmacology, Volume 119, pp. 356-64.

[103] Martinez-Medina, Ainhoa, Victor Flors, Martin Heil, Brigitte Mauch-Mani, Corne M.J. Pieterse, Maria J. Pozo, Jurriaan Ton, Nicole M. van Dam \& Uwe Conrath, 2016. Recognizing Plant Defense Priming. Trends in Plant Science, 21(10), pp. 81822.

[104]Ronsted, Nina, Matthew R.E. Symonds, Trine Birkholm, Soren Brogger Christensen, Alan W. Meerow, Marianne Molander, Per Molgaard, Gitte Petersen, Nina Rasmussen, Johannes van Staden, Gary I. Stafford \& Anna K. Jager, 2012. Can Phylogeny Predict Chemical Diversity and Potential Medicinal Activity of Plants? A Case Study of Amaryllidaceae. BMC Evolutionary Biology, Volume 12, p. 182.

[105]Beck, J., M. Boller, A. Erhardt \& W. Schwanghart, 2014. Spatial bias in the GBIF database and its effect on modeling species' geographic distributions. Ecological Informatics, Volume 19 pp.10-5. 